\title{
Effect of Nitrogen Source, Crop Maturity Stage and Storage Conditions on Phenolics and Oxalate Contents in Vegetable Amaranth (Amaranthus hypochondriacus)
}

\author{
Cecilia Moraa Onyango ${ }^{1}$, Jeremy Harbinson ${ }^{2}$, Jasper Kathenya Imungi ${ }^{3}$, Richard Ndemo Onwonga ${ }^{4}$, \\ \& Olaf van Kooten ${ }^{2}$ \\ ${ }^{1}$ Department of Plant Science and Crop Protection, University of Nairobi, Kangemi, Kenya \\ ${ }^{2}$ Department of Plant Sciences, Horticultural Supply Chains Group, Wageningen University, AA Wageningen, \\ The Netherlands \\ ${ }^{3}$ Department of Food Science, Nutrition and Technology, University of Nairobi, Kangemi, Kenya \\ ${ }^{4}$ Department of land Resource management and Agricultural Technology, University of Nairobi, Nairobi, Kenya \\ Correspondence: Cecilia Moraa Onyango, Department of Plant Science and Crop Protection, University of \\ Nairobi, P. O. Box 29053-00625, Kangemi, Kenya. E-mail: cecilia.onyango@uonbi.ac.ke
}

Received: March 27, 2012 Accepted: April 12, 2012 Online Published: June 6, 2012

doi:10.5539/jas.v4n7p219 URL: http://dx.doi.org/10.5539/jas.v4n7p219

\begin{abstract}
This study was designed to assess the effect of Diammonium Phosphate (DAP) fertilizer and cattle manure on the accumulation of total phenolics, quercetin and oxalates during growth and storage of vegetable amaranth (var. Amaranthus hypochondriacus L). Field trials were set up at the University of Nairobi Field Station-Upper Kabete Campus, Kenya during the long (March -May) rains of 2007 and 2008. Trials were laid out in a randomized complete block design with four fertilization treatments: 20 , 40, and $60 \mathrm{~kg} \mathrm{~N} \cdot \mathrm{ha}^{-1}$ supplied by DAP (18:46:0), cattle manure $\left(40 \mathrm{~kg} \mathrm{Nha}^{-1}\right)$ and an unfertilized control variant. The vegetables were harvested at 6 , 7 , and 8 weeks after planting and either refrigerated $\left(4+1^{\circ} \mathrm{C}\right)$ or stored at ambient temperature $\left(20+3^{\circ} \mathrm{C}\right)$ for a period of 4 days. The vegetables were then analyzed for total phenolic, quercetin, total and soluble oxalates content before and after storage. The total phenolic content decreased with increasing $\mathrm{N}$, the extent of decrease depended on the level and source of N. DAP at $20 \mathrm{~kg} \mathrm{Nha}^{-1}$ had the same effect on the phenolic content as that of cattle manure at $40 \mathrm{~kg} \mathrm{Nha}^{-1}$. The levels of phenolics and quercetin increased with crop maturity while the converse was true for the oxalate content. During refrigeration, levels of phenolics increased whereas those of oxalates did not change appreciably. There was a decrease in phenolics content during storage at ambient temperatures. The vegetable amaranth accumulates higher levels of total phenolic and quercetin when grown with manure than with DAP for similar levels of $\mathrm{N}$. Total phenolics and quercetin levels increased, while that of oxalates decreased, with maturity of the vegetables. The accumulation of oxalates during the periods considered normal for growth are low enough to maintain their levels within safe limits for human consumption. Storage of the fresh vegetables at $4^{\circ} \mathrm{C}$ for limited periods improves their quality by increasing total phenolics and quercetin contents that also fulfill beneficial health functions in the human body.
\end{abstract}

Keywords: vegetable amaranth, fertilizer, phenolics, oxalates, storage

\section{Introduction}

Vegetable amaranth, members of the genus Amaranthus, are widely grown in the tropics. They are a group of fast growing $\mathrm{C} 4$ herbs that yield a harvestable product within 4-6 weeks after planting, which makes them attractive to resource-poor farmers. In some countries such as Kenya, they are largely grown by women thus providing them with a degree of financial independence and health nutrition (IPGRI, 2003). The dual purpose amaranth, Amaranthus hypochondriacus for instance is an important source of proteins (Carlsson, 1980) and vitamins A and $\mathrm{C}$ as well as minerals such as iron, calcium and magnesium (National Research Council, 1984) for a majority of people living in sub-Saharan Africa. In Kenya, for example, the diet of lower socio economic groups consists largely of maize and various traditional leafy vegetables, such as amaranth.

Vegetables deliver health benefits in addition to fulfilling physiological nutritional needs (Hasler, 1998). Their 
consumption is associated with protection against major diseases including cancer and cardiovascular diseases (Wargovich 2000; Kaur \& Kapoor 2001; Scalbert et al., 2005). The protective action of the vegetables has been attributed to the presence of antioxidants (Prior \& Cao, 2000). Studies have shown that the majority of the antioxidant activity may be from secondary metabolites rather than from vitamins $\mathrm{C}$ and $\mathrm{E}$, and $\beta$-carotene alone (Kähkönen et al., 1999). Moreover, a positive correlation between total phenolics and antioxidant activity in some vegetables such as amaranth and fruits has been reported (Gil et al., 2000; Pyo et al., 2004; Khandaker et al., 2008).

Earlier studies have established the abundance of antioxidants in Amaranthus leaves (Sokkanha \& Tiratanakul, 2006; Khandaker et al., 2008) and that there was a general trend towards increased antioxidant activity with increased total phenolics content in Amaranthus tricolor $\mathrm{L}$. The beneficial effects of phenolics make it important to understand the circumstances they are synthesized and accumulated in these plants. Among the group of flavonoids, quercetin has been reported to be a strong antioxidant (Hollman, 1997). It has been found to chelate metals, scavenge oxygen free radical and prevent oxidation of low density lipoprotein in in vitro studies (de Whalley et al., 1990; Kandaswami \& middleton, 1994).

Amaranths in addition to their high nutritional value also accumulate high levels of anti-nutritional factors such as oxalates (Vityakon \& Standal, 1989; Gupta et al., 2005). A growing body of evidence indicates that oxalate plays various functional roles in plants, including calcium regulation, plant protection and detoxification of certain metals (Franceschi \& Nakata, 2005). For instance, several plants such as buckwheat, taro and rice exude and/or accumulate oxalate in vivo to cope with aluminum and lead toxicity (Ma \& Miyasaka 1998; Yang et al., 2000). More importantly, oxalates can serve as an antioxidant to quench the oxidative burst during plant response to pathogen attacks (Cessna et al., 2000; Weir et al., 2006). A molecular genetic analysis confirmed a long-held hypothesis that calcium oxalate crystals act as an effective defense against chewing insects (Korth et al., 2006).

Despite their functional roles in plants, excess levels of oxalate in plants have long been a concern to human nutrition and health (Franceschi \& Nakata, 2005). The high levels of oxalate in any edible parts of vegetables and food crops significantly lowers their nutritional quality and lead to health concerns. Soluble oxalate decreases calcium bioavailability by forming calcium oxalate crystals (Radek \& Savage, 2008) which can also lead to the formation of kidney stones (Massey, 2003). Studies have shown that availability of plant nutrients can be an important factor in determining the activity of secondary metabolism within plants (Kopsell et al., 2003; Aires et al., 2006). Nitrogen is one of the most important factors controlling the yield and quality of vegetables (Juan et al., 2008). In developing countries, such as Kenya, nitrogen is often supplied as manure because of the prohibitive cost of synthetic fertilizers. However information on the effect of manure or inorganic fertilizers on the polyphenols and oxalic acid contents of vegetables is still scanty. Only a few studies (Stout et al., 1998; Juan et al., 2008) have investigated the effect of different levels of nitrogen on the total phenolics and oxalate contents of vegetables.

Secondary metabolites are also known to vary in amount and content depending on the age of the plant (Dumas et al., 2003). Although it has been reported that there exists a large variability in the levels of phenolic compounds at various stages of maturation (Ellnain-Wojtaszek et al., 2001) of some leafy vegetables, the changes that occur in the content of these chemicals at different growth stages of traditional leafy vegetables found in Sub-Sahan Africa is poorly understood. Further, information on the fate of the harvested amaranth vegetables during storage is limited and even more so the fate of their constituents.

The present study was therefore designed to assess the levels of total phenolic, quercetin, and total and soluble oxalates in vegetable amaranth (var. Amaranthus hypochondriacus) grown using a mineral fertilizer diammonium phosphate (DAP) and cattle manure, during different stages of maturity. The changes in the levels of these substances during storage at ambient and refrigerated temperatures were also investigated.

\section{Materials and Methods}

\subsection{Site Description}

The experiment was conducted at the University of Nairobi field station, Kabete Campus during the long rain seasons (March - May) of 2007 and 2008. Kabete is situated about $15 \mathrm{~km}$ to the West of Nairobi city and lies at Latitude $1^{\circ} 15^{\prime} \mathrm{S}$ and Longitude $36^{\circ} 44^{\prime} \mathrm{E}$, and at altitude $1930 \mathrm{~m}$ above sea level (Sombroek et al., 1982). Kabete has a bimodal distribution of rainfall, with long rains from early March to late May and the short rains from October to December (Taylor \& Lawes, 1971). The mean annual temperature is $18^{\circ} \mathrm{C}$. The soils in Kabete are characterized as deep, well drained, dark reddish-brown to dark brown, friable clay (Mburu, 1996).

\subsection{Experimental Design and Treatments}

The trials were laid out in a randomized complete block design with five fertilization treatments replicated three times as follows: one plot with cattle manure at $40 \mathrm{~kg} \mathrm{Nha}^{-1}$, three plots with DAP at 20, 40, and $60 \mathrm{~kg} \mathrm{Nha}^{-1}$, and an 
unfertilized control plot. The recommended rate of $\mathrm{N}$ for vegetable amaranth is $40 \mathrm{~kg} \mathrm{Nha}^{-1}$. The different rates were selected to evaluate the $\mathrm{N}$ effects on phenolics and oxalates when the amaranth is supplied with either half or one and half the recommended rate of $\mathrm{N}$.

\subsection{Agronomic Practices}

Amaranth seeds were obtained from Asian Vegetable Research and Development Centre (AVRDC) Tanzania.. The seeds were sown in a seedbed fertilized with either manure or diammonium phosphate (DAP; 18:46:0) fertilizer. The plots measured $2 \mathrm{~m} \times 2 \mathrm{~m}$ with inter-raw and intra-raw spacing of $0.15 \mathrm{~m} \times 0.10 \mathrm{~m}$ (Palada \& Chang, 2003). Care was taken in this trial to use a manure treatment and, where possible, cultivation practices that were comparable to those employed by local small-scale growers. Four seeds were planted in each hole, but two weeks after germination, the seedlings were thinned to one per hole. Irrigation was used whenever rainfall was insufficient to keep the soil moist at all times to avoid moisture stress. Physical weeding was done twice during the growing period using a hand hoe. The vegetables were harvested at 6,7 , and 8 weeks from planting by cutting-off the tender edible stems and leaves.

\subsection{Storage Trials on the Vegetables}

Bundles of average weight $0.45 \mathrm{~kg}$ from each fertilizer treatment harvested at 6,7 and 8 weeks after planting were stored at ambient $\left(20 \pm 3^{\circ} \mathrm{C}\right)$ and refrigerated $\left(4 \pm 1^{\circ} \mathrm{C}\right)$ temperatures for 4 days. Initially and at 2 days interval, the vegetables were analyzed for total phenolics, quercetin, total and soluble oxalates.

\subsection{Sample Preparation and Analysis}

The edible parts of the vegetables which consisted of leaves and tender stems were separated and freeze-dried. The residue was ground to pass through a $600 \mu \mathrm{m}$ sieve. The powder was stored in tightly closed plastic vials in a freezer $\left(-20^{\circ} \mathrm{C}\right)$ to await analyses for total phenolics, quercetinand total and soluble oxalates.

\subsection{Determination of Total Phenolics}

The total phenolic contents of the filtrate were measured with a slightly modified method of Ragazzi and Veronese (1973). To $1.0 \mathrm{~mL}$ of filtrate in a $25 \mathrm{~mL}$ volumetric flask, $1 \mathrm{~mL}$ Folin's Reagent $(1 \mathrm{~N})$ and $2 \mathrm{ml}$ of $20 \% \mathrm{Na}_{2} \mathrm{CO}_{3}$ were added and mixed thoroughly with a cyclomixer. The mixture was made to $25 \mathrm{~mL}$ with distilled water then allowed to stand at room temperature for 30 minutes. The absorbance of the mixture was measured at $720 \mathrm{~nm}$ on a UV-Visible spectrophotometer (UV mini 1240, spectrum bandwidth 5nm, Shimadzu Corporation, Tokyo, Japan). The concentration of total phenolics in the filtrate was determined using a standard curve prepared from known concentrations of pure gallic acid aqueous solutions subjected to the same analytical procedure. The concentration in the filtrates was used to calculate the total phenolic contents of the vegetables in $\mathrm{mg}$ gallic acid equivalent $/ \mathrm{g}$ on a dry weight basis.

\subsection{Determination of Quercetin}

Quercetin content was determined using the method of Bovy et al. (2002) with slight modifications. Into a $50 \mathrm{ml}$ plastic centrifuge tube, $50 \mathrm{mg}$ of the freeze-dried powder was weighed and $4 \mathrm{ml}$ of $62.5 \%$ aqueous methanol containing $2 \mathrm{~g} / \mathrm{L}$ tert-butylhydroquinone (TBHQ) were added, followed by $1 \mathrm{ml} 6 \mathrm{~N} \mathrm{HCL}$ and carefully mixed. The centrifuge tubes were closed and placed in a shaking water bath at $90^{\circ} \mathrm{C}$ for 2 hours. The extract was cooled, and made to $10 \mathrm{ml}$ with methanol and placed in an ultrasonic bath for 5 minutes. This was followed by centrifugation at $1360 \mathrm{~g}$ for 3 minutes. An aliquot of $1.5 \mathrm{ml}$ was then transferred to an Eppendorf tube and centrifuged at $3600 \mathrm{~g}$ for $10 \mathrm{~min}$. A1ml sample of the supernatant was then injected and eluted through HPLC (Column:Waters Nova-pak

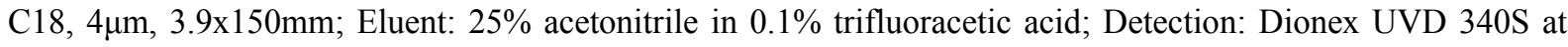
370nm; Flow: $0.9 \mathrm{ml} / \mathrm{min}$; Injection: $20 \mu \mathrm{l}$; Temperature: $30^{\circ} \mathrm{C}$ ). The concentration of quercetin was determined from a standard curve prepared from known concentrations of pure quercetin in methanol.

\subsection{Determination of Total and Soluble Oxalates}

For determination of total oxalates, $0.1 \mathrm{~g}$ of powder was weighed and mixed with $30 \mathrm{ml}$ of $1 \mathrm{M} \mathrm{HCl}$. Each mixture was then shaken in a water bath at $100^{\circ} \mathrm{C}$ for $30 \mathrm{~min}$. To each mixture was added $0.5 \mathrm{ml}$ of $5 \%$ calcium chloride and thoroughly mixed to precipitate out the calcium oxalate. The suspension was centrifuged at $800 \mathrm{~g}$ for 15 minutes and the supernatant decanted. The pellet was washed twice with $2 \mathrm{ml}$ of $0.35 \mathrm{M} \mathrm{NH}_{4} \mathrm{OH}$ then dissolved in $0.5 \mathrm{M}$ $\mathrm{H}_{2} \mathrm{SO}_{4}$. The solution was titrated with standard solution of $0.1 \mathrm{M} \mathrm{KMnO}_{4}$ with the temperature being maintained at $60^{\circ} \mathrm{C}$ to a faint violet color that persisted for at least 15 seconds (AOAC, 1999). For soluble oxalates, the same procedure was used except the extraction was done using $30 \mathrm{ml}$ distilled water. The total and soluble oxalate contents were calculated as percent of dry weight.

\subsection{Statistical Analysis}


Data obtained from both fresh and stored samples were subjected to the general analysis of variance (ANOVA), using Genstat statistical software (Payne et al., 2006) to check for both main effects of treatments and their interactions. Fisher's least significant difference (LSD) test was used to identify significant differences among treatment means $(\mathrm{P}<0.05)$.

\section{Results and Discussion}

\subsection{Total Phenolic and Quercetin Contents}

The levels of total phenolics across all treatments ranged between 50 and $80 \mathrm{mgGAE} / \mathrm{g}$ dry weight (Figure 1). These levels are higher than the $45.5 \mathrm{mg} / \mathrm{g}$ recorded in leaves of Larrea tridentata (D.C) a desert shrub (Hyder et al., 2002), but are less than $98.6 \mathrm{mg} / \mathrm{g}$ recorded in leaves of other desert shrubs (Hollechek et al., 1990). The phenolic contents differed significantly $(\mathrm{P}<0.05)$ across the sources of $\mathrm{N}$ and stage of maturity. The highest content was recorded in the manure and control plots at all maturity stages. The use of DAP led to a decrease in the phenolic contents. The effect of DAP on total phenolics content was increased with increasing levels of N. This could be probably due to the effect that nitrogen has on growth rate of plant. As the carbon/nutrient balance theory predicts, in terms of a high plant photosynthetic activity relative to the nitrogen supply, the excess of carbon is allocated to phenolics, a nitrogen-free defense substance (Yongke et al., 2005). Recent work by Sousa et al (2008) demonstrated an overall trend of higher total phenolics concentration in organically grown tronchuda cabbage, accompanied by lower plant fresh weight, as compared with conventionally fertilized samples. They suggested that the lack of nutrients, particularly insufficient nitrogen supply as a result of a low mineralization rate under organic production, could have boosted synthesis of phenolic compounds while limiting rapid growth of new leaves.

These results are in agreement with those of $\mathrm{Li}$ et al. (2008) who found that the total phenolics concentrations of leaf mustard (Brassica juncea Coss) were considerably decreased by increasing nitrogen supply. This negative correlation between nitrogen application and total phenolics could be explained by the protein competition model (PCM) (Jones \& Hartley, 1999). The PCM hypothesis makes a contingent prediction: when biomass increases in response to elevated nitrogen nutrition, phenolic concentrations will decline because increased protein demand for growth will decrease partitioning of carbon skeletons to phenolics (Jones \& Hartley, 1999).

Additionally, water availability, mineral and organic nutrients of the soil have been found to have a marked effect on the phenolic contents of plants (Barberan \& Espin, 2001). Under conditions of abundant insulation normally encountered in the tropics, the rate of photosynthesis of carbohydrates may be so high that if the levels of available nitrogen and minerals are low, they get quickly depleted by synthesis of primary metabolites. The excess carbohydrates can then only be shunted to production of nitrogen- and mineral-free molecules such as the phenolic compounds (Waterman et al., 1984). This is probably what happened with the plants in the control and manure plots. It has also been shown that the biosynthesis of phenolic compounds can be induced by sunlight (Harbowy \& Balentine, 1997). This could explain the higher levels of phenolics recorded in vegetable amaranth used in this study which was grown under tropical conditions where sunlight is not limiting. The presence of these compounds in green stems and leaves is related to deterring herbivory, with protection of photosynthetic tissues from damage by ultra-violet radiation being a secondary function (Gonzalez-Coloma et al., 1988).

Quercetin: There were significant differences in quercetin content between the two years of study. Significantly low amounts of quercetin were recorded in year 1 than in year 2 (Figure 2). In year 1 there were no clear differences in quercetin content across the different sources of N. In year 2 there were distinct differences with manure $40 \mathrm{~kg} \mathrm{~N} \mathrm{ha}^{-1}$ giving higher contents of quercetin than DAP at the same rate. Just as observed for the total phenolics, the quercetin content decreased with increasing rates of $\mathrm{N}$ supplied as DAP (Figure 2). The marked differences in quercetin content between year 1 and 2 may be attributable to sunshine hours the crop was exposed to during the growing season and the cooler air temperatures in year 1 than in year 2 (Table 1). Patil et al (1995) have shown that metereological factors (including temperature and rainfall patterns) have a stronger influence on quercetin concentration in onion cultivars than soil factors or plant maturity. Thus, the most critical factors for the accumulation of flavonoids like quercetin (e.g. temperature and rainfall) are also the ones that are more difficult to control in open air.

There was a significant difference in content of quercetin between fertilizer treatments and time of harvesting in year 2 (Figure 2). The quercetin contents increased significantly $(\mathrm{P}<0.05)$ between weeks 6 and 8 in all treatments except with the $60 \mathrm{~kg} \mathrm{Nha}^{-1} \mathrm{DAP}$ in year 2 . The highest increase occurred at week 8 when $20 \mathrm{~kg} \mathrm{~N} \mathrm{ha}^{-1} \mathrm{DAP}$ and 40 $\mathrm{kg} \mathrm{Nha}^{-1}$ manure were used. Use of higher levels of $\mathrm{N}$ supplied as DAP $\left(40 \mathrm{~kg} \mathrm{~N}^{-1}\right)$ resulted in a slight increase in quercetin content between week 6 and 8 . At $60 \mathrm{~kg} \mathrm{~N} \mathrm{ha}^{-1}$, the quercetin content of week 6 harvest was almost equal to that of week 8 harvest. Martirosyan et al. (2003 found that rutin is mostly produced by Amaranthus in the 
stage of blossoming. According to Kandil et al. (2004), rutin can be changed into quercetin or other compounds during leaf senescence. In this study, the vegetable amaranth started flowering at week 8 and this could explain the increase in quercetin content in all treatments.

Table 1 . Weather summary during the growing period of vegetable amaranth

2007

\begin{tabular}{lllll}
\hline Month & Week & $\begin{array}{l}\text { Rainfall per } \\
\text { week }\end{array}$ & $\begin{array}{l}\text { Temperature per } \\
\text { week }\end{array}$ & $\begin{array}{l}\text { Sunshine } \\
\text { per week }\end{array}$ \\
& & $(\boldsymbol{m m})$ & $\boldsymbol{\rho}$ C) & (Hrs) \\
\hline March & 1 & 0.1 & 19.7 & 9.5 \\
& 2 & 13.3 & 20 & 10.5 \\
& 3 & 23.4 & 20.5 & 9.2 \\
& 4 & 7.0 & 18.9 & 7.0 \\
& 5 (2days) & 15.7 & 20.0 & 6.4 \\
& 1 & 3.8 & 20 & 5.2 \\
& 2 & 124.1 & 19.7 & 2.1 \\
& 3 & 441.7 & 19.5 & 4.4 \\
& 4 & 204.1 & 18.9 & 6.7 \\
& 5 (2days) & 5.4 & 19.5 & 8.4 \\
& 1 & 1.0 & 18.8 & 6.4 \\
& 2 & 15.2 & 18 & 3.7 \\
& 3 & 64.5 & 18.8 & 5.8 \\
& 4 & 17.0 & 18.7 & 7.3 \\
& 5(3days) & 85.6 & 18.6 & 6.1 \\
\hline
\end{tabular}

Source: Kabete Meteological station, Nairobi. Kenya

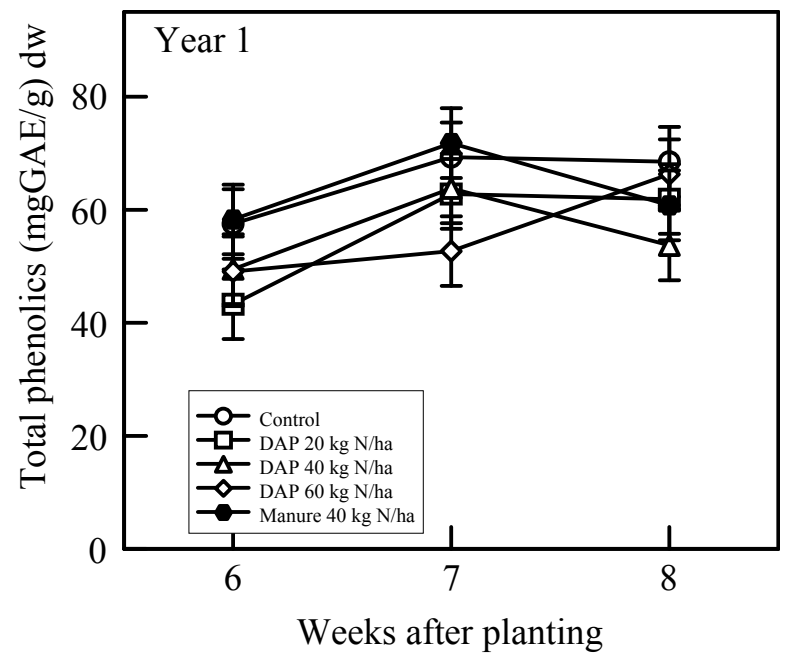

2008

\begin{tabular}{|c|c|c|c|c|}
\hline Month & Week & $\begin{array}{l}\text { Rainfall } \\
\text { per week } \\
(\mathrm{mm})\end{array}$ & $\begin{array}{l}\text { Temperature } \\
\text { per week } \\
(C)\end{array}$ & $\begin{array}{l}\text { Sunshine } \\
\text { per week } \\
\text { (Hrs) }\end{array}$ \\
\hline \multirow[t]{5}{*}{ March } & 1 & 3.1 & 20.2 & 9.0 \\
\hline & 2 & 1.7 & 19.9 & 8.8 \\
\hline & 3 & 35.5 & 21.0 & 8.0 \\
\hline & 4 & 137.6 & 19.5 & 3.7 \\
\hline & 5(2days) & 0.2 & 18.7 & 6.3 \\
\hline \multirow[t]{6}{*}{ April } & 1 & 0 & 19.0 & 9.1 \\
\hline & 2 & 84.9 & 18.7 & 5.9 \\
\hline & 3 & 16.7 & 19.1 & 8.3 \\
\hline & 4 & 102.6 & 18.1 & 6.6 \\
\hline & 5(2days) & 0 & 19.3 & 7.4 \\
\hline & 1 & 0 & 18.2 & 8.2 \\
\hline \multirow[t]{4}{*}{ May } & 2 & 2.5 & 19.0 & 7.0 \\
\hline & 3 & 0 & 17.6 & 6.4 \\
\hline & 4 & 8.0 & 17.2 & 4.2 \\
\hline & 5(2days) & 1.2 & 17.1 & 1.0 \\
\hline
\end{tabular}

Figure 1. Effects of diammonium phosphate fertilizer, manure and maturity at harvest on total phenolic content of vegetable amaranth (A. hypochondriacus) $(\mathrm{GAE}=$ Gallic acid Equivalent $)$ 

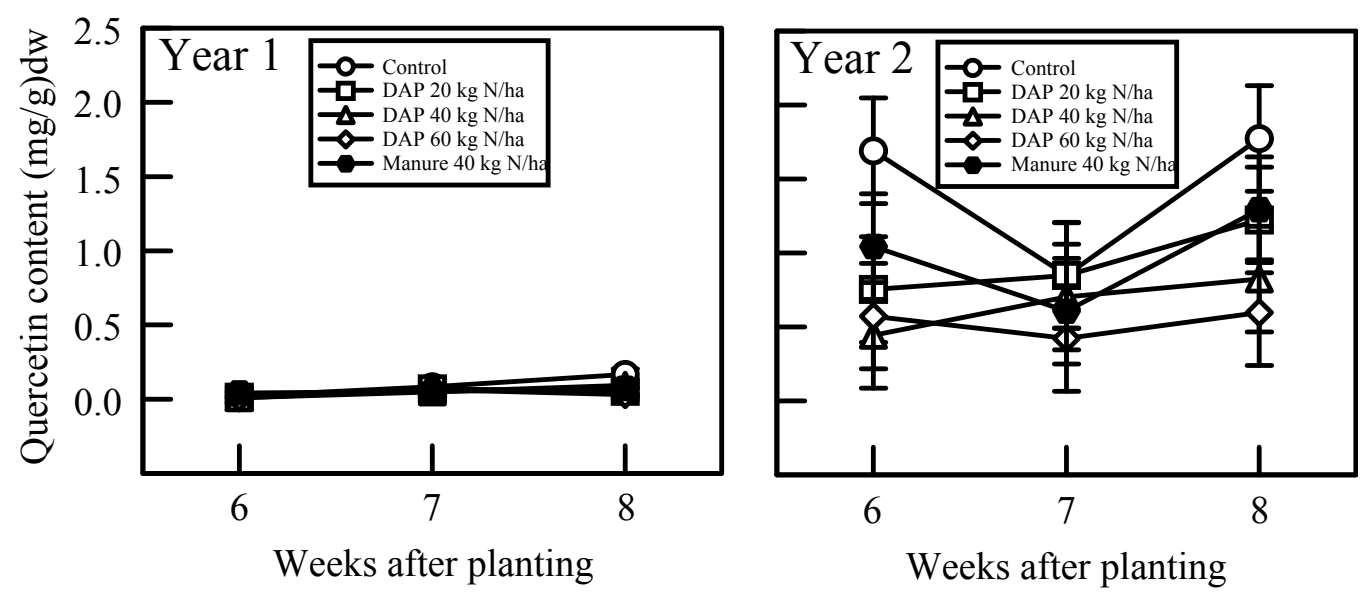

Figure 2. Effects of diammonium phosphate fertilizer, manure and maturity at harvest on quercetin content of vegetable amaranth (A. hypochondriacus)

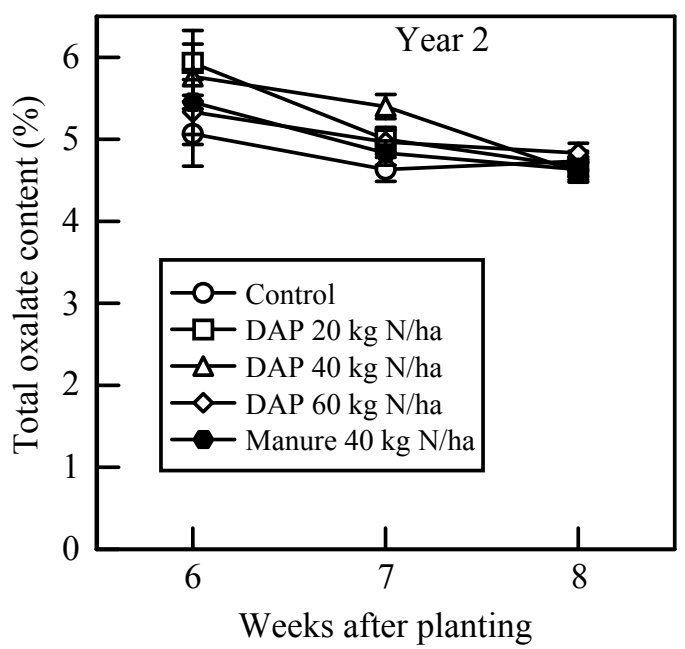

Figure 3. Effects of diammonium phosphate fertilizer, manure and maturity at harvest on total oxalate content of vegetable amaranth (A. hypochondriacus)

\subsection{Total and Soluble Oxalates}

There were no significant differences between treatments in terms of the total and soluble oxalate contents (Figure $3)$. The total oxalates decreased with stage of maturity of the vegetables for all treatments but this decrease was not significant $(\mathrm{P}<0.05)$. These results are comparable with those of Kitchen and Burns (2006) working with Dark Green Bloomsdale spinach who found that total oxalate content was maximum at 32 days after planting and decreased subsequently as the plants developed vegetatively. Some weeds have been known to accumulate compounds such as oxalates to act as a defense against chewing insects (Korth et al., 2006). This could be the case in Amaranthus hypochondriacus.

There were no significant differences in soluble oxalates across the fertilizer treatments as well as maturity at harvest (Figure 4). The soluble oxalates remained unchanged through the growing period. The soluble oxalate contents ranged between 3 and 4\% dry weight in all treatments (Figure 4). This agrees with results reported by Rahman et al working with napier grass (Pennisetum purpureum Schumach) who found that the soluble oxalate content was not change with increased levels of $\mathrm{N}$ fertilization in all cut forages. Schmidt et al (Schmidt et al., 1971) reported 2.9\% in Amaranthus cruentus L., while Radek and Savage (Radek \& Savage, 2008) reported 4.7\% soluble oxalates in Amaranthus viridis and 4.4\% in Amaranthus cruentus.

The results (Figure 4) fall between the ranges reported by Schmidt et al (1971) and Radek and Savage (2008). This translates to consumption of between $0.5 \mathrm{~g}$ and $0.6 \mathrm{~g}$ of oxalates per $100 \mathrm{~g}$ of fresh vegetable. The oxalate levels in the vegetables that received manure and DAP were within safe limits as long as consumption does not exceed the equivalent of $800 \mathrm{~g}$ of fresh leaves per day (Schmidt et al., 1971) which is far above the amounts normally 
consumed, for example, in Kenya which are 200g fresh weight per day (Personal observation). Cooking by boiling has been shown to significantly reduce the amount of soluble oxalates in Colocasia esculenta (L) Schott, and Oxalis tuberose (Catherwood et al., 2007; Albihn Savage, 2001) through leaching into the cooking water. Since vegetable amaranth is cooked before consumption, it is expected that during cooking, which involves boiling in water which is thereafter discarded the levels of soluble oxalates and therefore the levels of total oxalates in the vegetables as consumed will be substantially reduced.

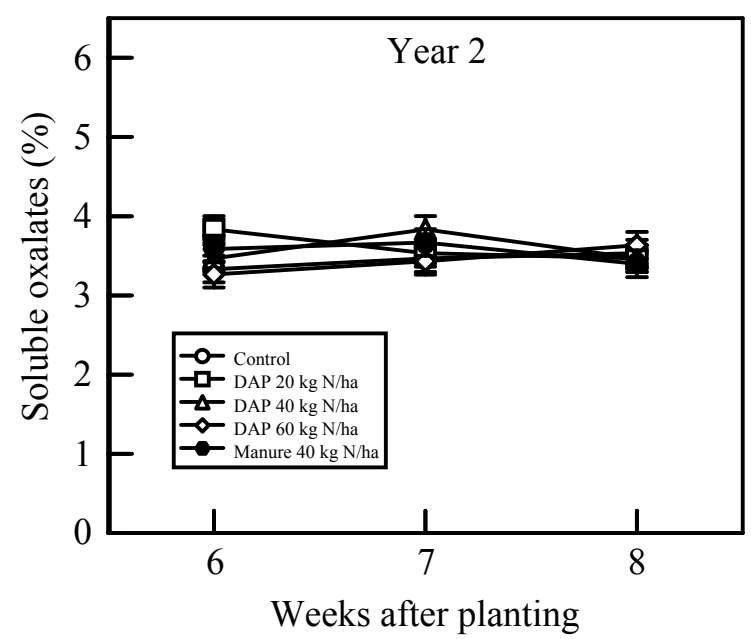

Figure 4. Effects of diammonium phosphate fertilizer, manure and maturity at harvest on total oxalate content of vegetable amaranth (A. hypochondriacus)

\subsection{Total Phenolics and Quercetin Content during Storage}

There were no significant differences in the levels of total phenolic and quercetin contents during storage for both years. The N source and levels did not cause significant changes on total phenolics and quercetin contents during storage. However, maturity at harvest as well as storage temperature caused in significant changes in the phenolics and quercetin contents $(\mathrm{P}<0.05)$. There was a gradual decrease in total phenolic throughout the storage period. The decrease in the phenolics was greater when the vegetables were stored at ambient temperatures (Figure 5). For quercetin (Figure 6), there was a slow initial increase after 2 days in storage followed by a gradual decrease after 4 days in storage under refrigeration $\left(4^{\circ} \mathrm{C}\right)$. Storage of the vegetable at ambient $\left(20 \pm 3^{\circ} \mathrm{C}\right)$ temperatures led to an accelerated decrease of the quercetin content.

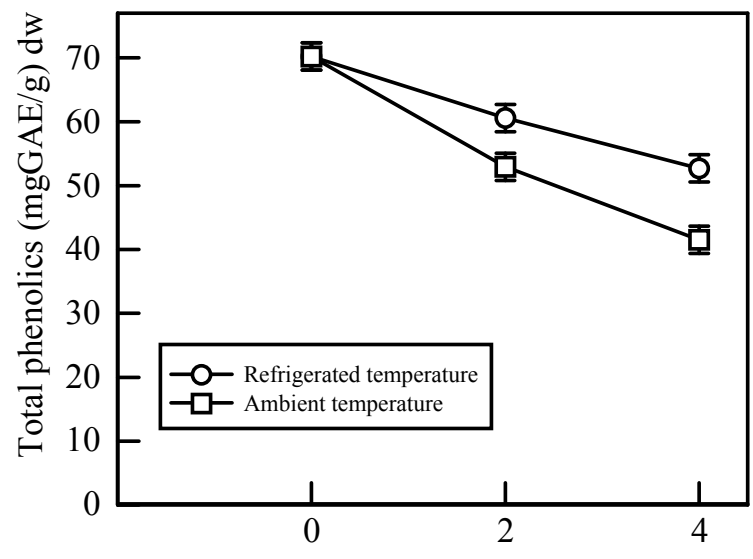

Days in storage

Figure 5. Effect of temperature and duration of storage on total phenolic content of vegetable amaranth 


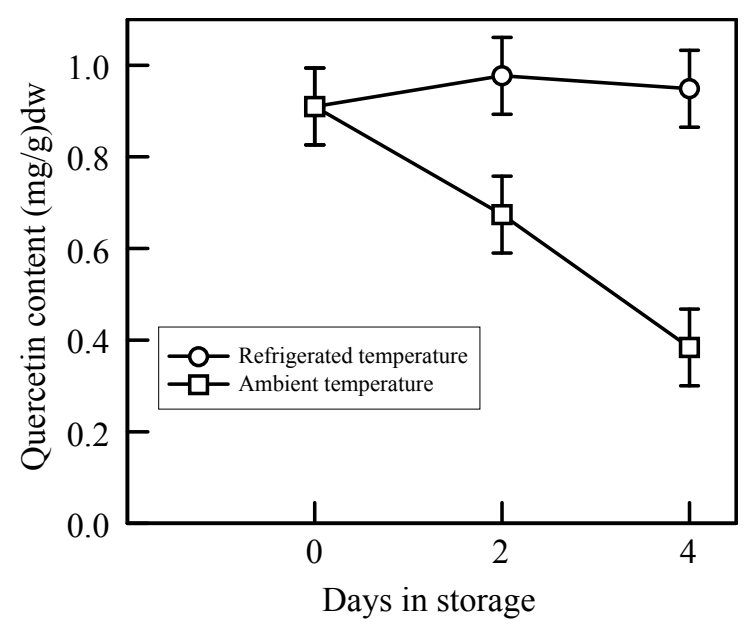

Figure 6. Effect of temperature and duration of storage on quercetin content of vegetable amaranth

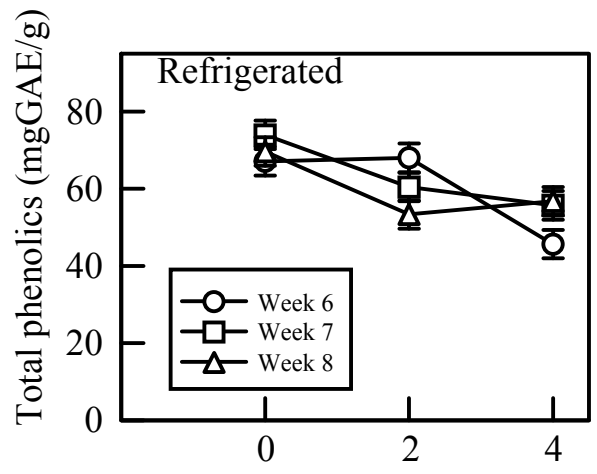

Days in storage

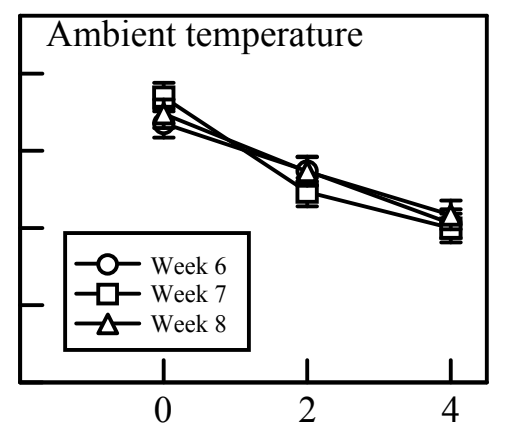

Days in storage

Figure 7. Effect of maturity at harvest, temperature and duration of storage on total phenolic content of vegetable amaranth (A. hypochondriacus)

Changes in both total phenolics and quercetin content depended on the maturity at harvest. Vegetables harvested 6 weeks after planting and stored refrigeratred had their total phenolics content increase after 2 days followed by a gradual decrease (Figure 7). For vegetables harvested 8 weeks after planting, the increase in total phenolics was recorded after 4 days in refrigeration. Vegetables harvested at 7 weeks after planting had a non-significant increase in total phenolics after 2 days in refrigeration followed by a gradual decrease. Unlike total phenolics, quercetin content of vegetables harvested 7 and 8 weeks after planting increased significantly while that of the 6 weeks harvest decreased when the vegetables were refrigerated (Figure 8).

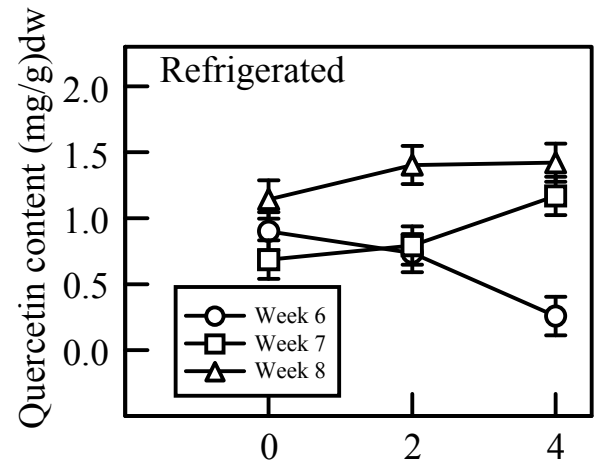

Days in storage

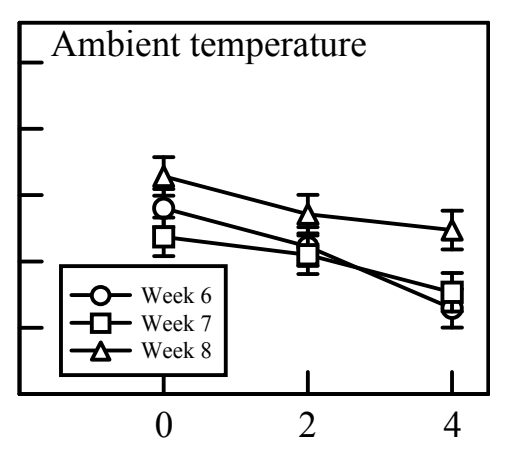

Days in storage

Figure 8. Effect of maturity at harvest, temperature and duration of storage on quercetin content of vegetable amaranth (A. hypochondriacus) 
Venere et al (2005) storing escarole (Cichorium endivia L. latifolium group) and radicchio (Cichorium intybus L. (rubifolium group) at $4^{\circ} \mathrm{C}$ found that in escarole, the most abundant phenolic compound increased markedly during storage after the fifth day. In radicchio, the phenolic content showed marked fluctuations during storage: after an initial increase, it showed a gradual decrease, followed by a sharp increase around the ninth day in storage. The current results are comparable with those of Venere et al (2005) although our storage period was limited to 4 days after which the amaranth becomes unsaleable.

The total phenolics and quercetin contents increased after 2 or 4 days in storage at refrigerated $\left(4 \pm 1^{\circ} \mathrm{C}\right)$ temperature depending on the stage of maturity at harvest. These observations agree with reports by Souzan and Abd El-aal (2007) and Rivera et al. (2006), both groups working with lettuce. They found that the phenolics content increased during low storage temperature reaching a maximum after 2 and 3 days, then decreased marginally until the end of 8 days in storage. The basis for the increase is not easy to explain, but there is a possibility that depending on the amount and type of stress, the synthesis of phenolic compounds may be induced as a result of increased transcription of genes encoding the enzymes in their biosynthetic pathway (Ferrante et al., 2009); the synthesis of phenolics is known to be up regulated in exposure to light, cold and wounding (Tavarini et al., 2007). While this model is attractive its relevance to Amaranthus which is a tropical genus and therefore probably chilling sensitive would need to be confirmed. In storage at high temperatures, most of the phenolics may be lost in the respiration and oxidation processes which results in the decrease observed in this study (Figure 5).

\subsection{Total and Soluble Oxalates during Storage}

There were no significant changes in both total and soluble oxalates during refrigeration as well as ambient temperatures of storage. The fresh samples had an average total oxalate content of $5.1 \%$ which after storage for 4 days in the refrigerator was found to be 5\% and while that of the material stored at ambient temperatures was $5.2 \%$. The soluble oxalate content of the fresh samples was $3.4 \%$ which increased to $3.5 \%$ after storage for 4 days in the refrigerator and to $3.7 \%$ when stored at ambient temperatures. A small increase in soluble oxalates during storage has been shown to be related to an overall loss in moisture content in other vegetables (Catherwood et al., 2007). This can explain the small increase shown in vegetable amaranth after 2 and 4 days in storage. These results indicate that minimal changes occurred in soluble oxalates during storage. This is in agreement with those of Kuan (2003) working with soyabeans who found that the levels of soluble oxalates remained constant during 6 months of storage at $-20^{\circ} \mathrm{C}, 4^{\circ} \mathrm{C}$ and $25^{\circ} \mathrm{C}$; the temperatures used $4^{\circ} \mathrm{C}$ and $25^{\circ} \mathrm{C}$ were similar to those used in this study, albeit considerably shorter storage periods were involved.

\section{Conclusion}

The vegetable amaranth (var. Amaranthus hypochondriacus) accumulates higher levels of total phenolic and quercetin when grown using manure compared to DAP for similar levels of $\mathrm{N}\left(40 \mathrm{~kg} \mathrm{Nha}^{-1}\right)$. The total phenolics and quercetin levels increase with maturity of the vegetables whereas the converse was true for the oxalates. The accumulation of oxalates during the periods considered normal for amaranth growth were low enough and hence within safe limits for human consumption. Low temperature storage of $A$. hypochondriacus contributes to the maintenance of acceptable levels of both phenolics and quercetin. Both total and soluble oxalates do not change significantly during storage of vegetable amaranth (var. A. hypochondriacus) for up to 4 days.

The contents of total oxalates remained unchanged during storgae under both ambient and refrigerated storage. It is possible that these conditions do not influence the content of oxalates found in this vegetables. The quantities of soluble oxalates found in Amaranthus hypochondriacus used in this study are therefore not high enough to cause public health concerns. From the nutritional point of view therefore, vegetable amaranth consumption offer full beneficial health functions in the human body. Further research on the effect of other types of fertilizers and different modes of application is recommended.

\section{Acknowledgements}

This study was made possible through financial support from Nuffic - Netherlands Organization for International Cooperation in Higher Education and Research.

\section{References}

Aires, A., Rosa, E., \& Carvalho, R. (2006). Effects of nitrogen and Sulfur fertilization on glucosinolates in the leaves and roots of broccoli sprouts (Brassica oleracea var. italica). Journal of the Science of Food and Agriculture, 86, 1512-1516. http://dx.doi.org/10.1002/jsfa.2535

Albihn, P., \& Savage, G. P. (2001b). The bioavailability of oxalate from Oca (Oxalis tuberose). J. Urol., 166, 420-422. 
AOAC, (1999). Association of Official Analytical Chemists, Official Methods of Analysis. Washington DC.

Barberan-Tomas, A. F., \& Espin, C. J. (2001) Phenolic compounds and related enzymes as determinants of quality in fruits and vegetables. J. Sci. Food Agric., 81, 853-876. http://onlinelibrary.wiley.com/doi/10.1002/jsfa.885

Bar-Yosef, B. (1991). The hidden half. In Plant roots (Waisel, Y., Eschel, A. and Kafkafi V. (eds.) pp. 529-557. Marcel Dekker. New York. USA.

Bovy, A., Vos, de R., Kemper, M., Schijlen, E., Pertejo, A. M., Muir, S., ... Tunen, van Arjen. (2002). High-Flavonol Tomatoes resulting from the heterologous expression of the maize transcription factor genes LC and C1. The Plant Cell, 14, 2509-2526.

Carlsson, R. (1980). Quantity and quality of leaf protein concentrates from Atriplex hortensis, Chenopodium quinoa, and Amaranthus caudatus grown in Southern Sweden. Acta Agric Scand, 30, 418-426.

Catherwood, D. J., Savage, G. P., Mason, S. M., Scheffer, J. J. C., \& Douglas, J. A. (2007). Oxalate content of cormels of Japanese taro (Colocasia esculenta (L) Schott) and the effect of cooking. Journal of Food Comp. Anal., 20, 147-151.

Cessna, S. G., Sears, V. E., Dickman, M. B., \& Low, P. S. (2000). Oxalic acid, a pathogenicity factor for Sclerotinia sclerotiorum, suppresses the oxidative burst of the host plant. Plant Cell, 12, 2191-2200.

de Whalley, C., Rankin, S. M., Hoult, J. R. S., Jessup, W., \& Leake, D. S. (1990). Flavonoids inhibit the oxidative modification of low density lipoproteins by macrophages. Biochem. Pharmacol., 39, 1743-1750.

Dumas, Y., Dadomo, M., Di Lucca, G., \& Grolier, P. (2003). Effects of environmental factors and agricultural techniques on antioxidant content of tomatoes. A review. Journal of the Science of Food and Agriculture, 83, 369-382. http://dx.doi.org/10.1002/jsfa.1370

Ellnain-Wojtaszek, M., Kurczynski, Z., Kasprzak, J. (2001). Analysis of the content of flavonoids, phenolic acids as well as free radicals from Ginkgo biloba L. leaves during the vegetative cycle. Acta Pol. Pharm., 58, 205-209.

Ferrante, A., Martinetti, L., \& Maggiore, T. (2009). Biochemical changes in cut vs. intact lamb's lettuce (Valerianella olitoria) leaves during storage. International Journal of Food Science and Technology, 44, 1050-1056. http://dx.doi.org/10.1111/j.1365-2621.2008.01891.

Franceschi, V. R., \& Nakata, P. A. (2005). Calcium oxalate in plants, formation and function. Ann Rev Plant Biol, 56, 41-71. http://dx.doi.org/abs/10.1146/annurev.arplant.56.032604.144106

Gil, M. I., Tomas-Barberan, F. A., Hess, P. B., Holcroft, D. M., \& Kader, A. A. (2000). Antioxidant activity of pomegranade juice and its relationship with phenolic composition and processing. Journal of Agricultural and Food chemistry, 48, 4581-4589.

Goldberg, D. M., Tsang, E., Karumanchiri, A., \& Soleas, G. J. (1998). Quercetin and p-Coumaric Acid Concentrations in Commercial Wines. Am. J. Enol. Vitic., 49, 142-151.

Gonzalez-Coloma, A., Wisdom, C. S., \& Rundel, P. W. (1988). Ozone impact on the antioxidant nordihydroguaiaretic content in the external leaf resin of Larrea tridentate. Biochem. Syst. Ecol., 16, 59-64.

Gupta, S, Lakshmi, J. A., Manjunath, M. N., \& Prakash, J. (2005). Analysis of nutrient and antinutrient content of underutilized green leafy vegetables. LWT- Food Science and Technology, 38, 339-345. http://dx.doi.org/10.1016/j.lwt.2004.06.012

Harbowy, M. E., \& Balentine, D. A. (1997). Tea chemistry. Crit. Rev. Plant Sci., 16, 415-480.

Hasler, C. M. (1998). Functional foods: their role in disease prevention and health promotion. Food Technology, 52, 63-70.

Holechek, J. L., Munshikpu, A. V., Saiwana, L., Nunez-Hernandez, G., Valdez, R., Wallace, J. D., \& Cardenas, M. (1990). Influences of six shrub diets varying in phenol content on nitrogen retention by goats. Tropical Grasslands, 24, 93-98.

Hollman, C. H. P., Tripp van, M. P. J, Buysman, N. C. P. M., Gaag, v. d. S. M., Mengelers, J. B. M. Vries de, H. M. J, \& Katan, B. M., (1997). Relative bioavailability of the antioxidant flavonoid quercetin from various foods in man. FEBS Letters, 418, 152-156.

Hollman, P. C. H., van der Gaag, M. S., Mengelers, M. J. B., van Trijp, J. M. P., de Vries, J. H. M., \& Katan, M. B. (1996). Absorption and disposition kinetics of the dietary antioxidant quercetin in man. Free Radical Biol. Med., 21, 703-707. 
Hyder, P. W., Fredrickson, E. L., Estell, R. E., Tellez, M., \& Gibbens, R. P. (2002). Distribution and concentration of total phenolics, condensed tannins and nordihydroguaiaretic acid (NDGA) in creosotebush (Larrea tridentate). Biochemical Systematics and Ecology, 30, 905-912.

IPGRI. (2003). Rediscovering a forgotten treasure. IPGRI Public Awareness Forum. Nairobi, Kenya. IPGRI/National Museums of Kenya. http://ipgri- pa.grinfo.net/index.php.

Jones, C. G., \& Hartley, S. E. (1999). A protein competition model of phenolic allocation. Oikos, 86, 27-44.

Juan, L., Zhujun, Z., \& Jóska, G. (2008). Effects of nitrogen and sulfur on total phenolics and antioxidant activity in two genotypes of leaf mustard. Journal of Plant Nutrition, 31, 1642-1655. http://dx.doi.org/abs/10.1080

Kähkönen, M. P., Hopia, A. I., Vuorela, H. J., Rauha, J. P., Pihlaja, K., Kujala, S. T., \& Heinonen, M. (1999). Antioxidant activity of plant extracts containing phenolic compounds. Journal of Agricultural Food Chemistry, 47, 3954-3962.

Kandaswami, C., \& Middleton, Jr., E. (1994). Free radical scavenging and antioxidant activity of plant flavonoids. Adv. Exp. Med. Biol., 366, 351-376.

Kaur, C., \& Kapoor, H. C. (2001). Antioxidants in fruits and vegetables-the millenium's health. International Journal of Food Science and Technology, 36, 703-725.

Khandaker, L., Ali, B. Md., \& Oba, S. (2008). Total polyphenol and antioxidant activity of red amaranth (Amaranthus tricolor L.) as affected by different sunlight levels. J. Japan Soc. Hort. Sci., 77(4), 395-401. http://ci.nii.ac.jp/naid/110006975677

Kitchen, J. W, \& Burns, E. E. (2006). The effect of maturity on the oxalate content of spinach (Spinacia oleraceae L.). Journal of Food Science, 30(4), 589-593. http://dx.doi.org/10.1111/j.1365-2621.1965.tb01807.x

Kopsell, D. E., Kopsell, D. A., Randle, W. M., Coolong, T. W., Sams, C. E., \& Curran-Celentano, J. (2003). Kale carotenoid remain stable while flavor compounds respond to changes in sulfur fertility. Journal of Agricultural and Food Chemistry, 51, 5319-5325.

Korth, K. L., Doege S. J, Park S. H., Goggin, F. L., Wang, Q., Gomez, S. K., Liu, G., Jia, L., \& Nakata, P. A. (2006). Medicago truncatula mutants demonstrate the role of plant calcium oxalate crystals as an effective defense against chewing insects. Plant Physiol, 141, 188-195. http://dx.doi.org/10.1104/pp.106.076737_

Kuan, J. Y. L. (2003). Changes of oxalate levels in soyabeans during storage. http://ift.confex.com/ift/2003/techprogram/paper_20056.htm (Accessed, July, 2008).

Li, J., Zhu, Z., \& Gerendás, J. (2008). Effects of nitrogen and sulfur on total phenolics and antioxidant activity in two genotypes of leaf mustard. Journal of Plant Nutrition, 31, 1642-1655.

López-Bucio, J., de la Vega, O. M., Guevara-García, A., \& Herrera-Estrella. (2000). Enhanced phosphorus uptake in transgenic tobacco plants that overproduce citrate. Nature Biotechnology, 18, 450-453.

Ma, Z., \& Miyasaka, S. C. (1998). Oxalate exudation by taro in response to Al. Plant Physiol, 118, 861-865.

Massey, L. K. (2003). Dietary influences on urinary oxalate and risk of kidney stones. Front Biosci, 8, S584-S594.

Mburu, M. W. K. (1996). The effect of irrigation, nitrogen fertilizer and planting density on bean (Phaseolus vulgaris) yield under different weather conditions. PhD Thesis. University of Reading, Britain.

Mohammed, A. A. (2002). Antioxidant activity of commonly consumed vegetables in Yemen. Mal. J. Nutr., 8(2), 179-189.

National Research Council. (1984). Amaranth: Modern prospects for an ancient crop. National Academy Press. Washington, USA. p. 74.

Palada M. C., \& Chang, L. C. (2003). Suggested cultural practices for vegetable amaranth. International cooperator's guide. Kalb, T. (ed) No.3 - 552. AVRDC. Taiwan.

Patil, B. S., Pike, L. M., \& Hamilton, B. K. (1995). Changes in quercetin concentration in onion (Allium cepa L.) owing to location, growth stage and soil type. New Phytol., 130, 349-355.

Payne, R., Murray, D., Harding, S., Baird, D., \& Soutar, D. M. (2006). Introduction to genstat for windows. Genstart $9^{\text {th }}$ Edition. Lawes Agricultural Trust. Rothamsted.

Prior, R. L., \& Cao, G. (2000). Antioxidant phytochemicals in fruits and vegetables; diet and health implications. HortScience, 35, 588-592. 
Pyo, Y. H., Lee, T. C., Logendra, L., \& Rosen, R. T. (2004). Antioxidant activity and phenolic compounds of Swiss chard (Beta vulgaris subspecies cycla) extracts. Food Chemistry, 85, 19-26.

Radek, M., \& Savage, G. P. (2008). Oxalates in some Indian green leafy vegetables. International Journal of Food Science and Nutrition, 59(3), 246-260.

Ragazzi, E., \& Veronese, G. (1973). Quantitative analysis of phenolic compounds after thin layer chromatographic separation. J. Chromatogr., 77, 369-375.

Ricardo, B. (1993). Amaranth.: In Encyclopaedia of Food Technology and Nutrition., Vol. 1. Academic Press, London.

Rivera, J. R. E., Stone, M. B., Stushnoff, C., Pilon-Smits, E., \& Kendall, P. A. (2006). Effects of ascorbic acid applied by two hydrocooling methods on physical and chemical properties of green leaf lettuce stored at $5^{\circ} \mathrm{C}$. J. Food Sci., 71, 270-276.

Scalbert, A., Manach, C., Morand, C., Remesy, C., \& Jimenez, L. (2005). Dietary polyphenols and the prevention of diseases. Cri. Rev. Food Sci. Nutr., 45, 287-306.

Schmidt, D. R., MacDonald, H. A., \& Brockman, F. E. (1971). Oxalate and nitrate contents of our tropical leafy vegetables grown at two soil fertility levels. Agronomy Journal, 63(4), 559-561.

Sokkanha, S., \& Tiratanakul, V. (2006). Effect of plastic vinyl cover and shading on the antioxidants level of selected indigenous vegetables. Asian Vegetable research and Development Centre (AVRDC).

Sombroek, W. G., Graun, H. M., \& Van der Pouw. (1982). Exploratory soil survey. Report No. E1. Ministry of Agriculture, Nairobi, Kenya.

Sousa, C. Pereira, D. M., Pereira, J. A., Bento, A., Rodrigues, M. A., Dopico-Garcia, S. et al. (2008). Multivariate analysis of tronchuda cabbage (Brassica oleracea L. var. costata DC) phenolics: influence of fertilizers. $J$. Agric. Food Chem, 56, 2231-2239.

Souzan, S. L., \& Abd El-aal, H. A. (2007). Minerals profile-Shelf life extension and nutritive value of fresh green leafy vegetables consumed in Egypt. African Crop Science Conference Proceedings, 8, 1817-1826. El-Minia, Egypt.

Stout, M. J., Brovont, R. A., \& Duffey, S. S. (1998). Effects of nitrogen availability on expression of constitutive and inducible chemical defenses in tomato (Lycopersicon esculentum). Journal of Chemical Ecology, 24(6), 945-963.

Tavarini, S., Degl'Innocenti, E., Pardossi, A, \& Guidi, L. (2007). Biochemical aspects in two minimally processed lettuces upon storage. International Journal of Food Science and Technology, 42, 214-219. http://dx.doi.org/10.1111/j.1365-2621.2006.01223.x

Taylor, S. A., \& Lawes, E. F. (1971). RaifallRainfall intensity, duration frequency data for stations in east Africa. EAMD. Technical memorandum No. 17.

Venere, D. D., Linsalata, V., Sergio, L., \& Bianco, V. V. (2005). Antioxidant phenolics in escarole and radicchio during storage of fresh-cut 'ready to-use' product. Acta Hort., 682, 1947-1951.

Vinson, J. A., Hao, Y., Su, X., \& Zubik, L. (1998). Phenol antioxidant quantity and quality in foods: Vegetables. J. Agric. Food Chem., 46, 3630-3634.

Wargovich, M. J. (2000). Anticancer properties of fruits and vegetables. HortScience ,35, 573-575.

Waterman, G. P., Ross, M. A. J., \& McKey, B. D. (1984). Factors affecting levels of some phenolic compounds, Digestibility and Nitrogen content of the mature leaves of Barteria fistulosa (Passifloraceae). Journal of Chemical Ecology, 10(3), 387-401.

Weir, T. L., Bais, H. P., Stull, V. J., Callaway, R. M., Thelen, G. C., Ridenour, W. M., Bhamidi, S., Stermitz, F. R., Vivanco, J. M. (2006). Oxalate contributes to the resistance of Gaillardia grandiflora and Lupinus sericeus to a phytotoxin produced by Centaurea maculosa. Planta, 223, 785-795.

Yang, Y. Y., Jung, J. Y., Song, W. Y., Suh, H. S., Lee, Y. (2000). Identification of rice varieties with high tolerance or sensitivity to lead and characterization of the mechanism of tolerance. Plant Physiol, 124, 1019-1026.

Yongke, L., Dan, Y., \& Yongming, H. (2005). Effects of UV-B, Nutrient, and Light Availability on Shoot Length and Phenolic Content of Myriophyllum spicatum (L.). Journal of Freshwater Ecology, 20(1), 59-63. 